\title{
MAPPING THE VERNACULAR ENVIRONMENT: SERBIAN VILLAGE ATLAS AS A STEP TOWARDS AN ECO-VILLAGE NETWORK
}

\section{A B S T R A C T}

The main research subject is forming optimal local models of the architectural and technological intervention in rural areas of the Republic of Serbia, as a way of climate change adaptation, as well as their feasibility study on the West Pomoravlje area. Each region has its own unique features. Thus, in the territory of the Republic of Serbia can be defined zones with the same local characteristics, using the following criteria of physical and human geography: geo-physiognomic characteristics, climatic characteristics, economic development, and level of urbanity. These criteria are defined as the most important. They are the primary determinants for choosing the architectural and technological interventions within the local model as a way of climate change adaptation.

The first part of research deals with the zoning of the Republic of Serbia and defining the zones with the same local characteristics. Atlas of villages, providing their current types and possible future models, will be created. The second part is based on the case study of one of the zones - West Pomoravlje zone. Villages and households within the zone will be analysed and sorted into the types and groups. Further research will be based on the examination of possibilities of transforming the existing villages into the eco-villages, mapping the most appropriate positions for new eco-villages and forming a potential eco-village network. 


\section{INTRODUCTION}

It is common knowledge that throughout history traditional architecture followed the requirements of the local environment and created in accordance with them. This primarily relates to the local materials and different responses to climate conditions, but we should not forget the influence of culture, religion, society. Regarding this question Ranko Radović wrote: "Traditional architecture is not a style; it is a philosophy of the world and life, nature and spirit of the place; it is an attitude towards life processes and materials, towards locality and authenticity". ${ }^{1}$ Today, the vernacular can still be strongly felt in rural areas of Serbia. On the other hand, in the new rural architecture we can notice only archetypical relation to the genuine vernacular.

Statistical Office of the Republic of Serbia provided the data for 2008. According to these data, almost $42 \%$ of Serbian population live in the settlements listed as "remaining" (rural and suburban areas). The Republic of Serbia is a developing country where single-family houses make up the largest percentage of the built environment. Economic conditions are rather poor in the rural areas, while energy losses are still high. Although Serbia possesses significant natural advantages, the level of utilization of renewable energy sources (solar energy, wind, moving water, geothermal energy, biomass...) is very low, and awareness of energy saving is rather negligible, especially in rural areas.

Following this information and having in mind the importance of rural areas and traditional architecture mentioned before, we started a large research of the villages in the Republic of Serbia, in order to create the Serbian Village Atlas. The aim of this project is to define villages with the same local characteristics, to describe and evaluate them, to define development opportunities and to provide possible solutions in the context of present problems in rural areas. Serbian Village Atlas should make a step towards wider sustainable development and climate change adaptation. It should also balance between basic users' needs, traditional principles, new design and technology, aesthetical and ethical values, etc. combining them in an understandable and acceptable way from the users' viewpoint.

In order to identify similarities and differences among rural areas in Serbia, their local specificities, as well as their strengths and weaknesses, we have started the project "Rural Areas in Serbia - the Village Atlas". The project is a starting point for research of rural villages in Serbia, its eventual aim being to find ways of improving the environment and quality of life in the villages and mitigating climate change in rural areas. The primary use of the Atlas should be as a database for future researches on various subjects regarding villages and rural areas in Serbia. 


\section{RURALISM IN THE REPUBLIC OF SERBIA}

Rural studies in Serbia has not had a continuity, but a number of researchers (sociologists, geographers, architects etc.) have left important impact in this domain, approaching ruralism differently.

Socio-cultural rural development in Serbia since the World War II has taken place in defined social and political conditions that directed development of both villages and cities. These conditions can be identified on general and on a specific level. General level is the level of ideology where conflict of old and new, traditional and modern took place. Specific level brought along specific actions directed toward annulment of differences between the village and the city. ${ }^{2}$ The process of deagrarianization is often an indicator of industrial and other progress of a country, and it is usually followed by an adequate urbanization. The urbanization process in former Yugoslavia was too slow comparing to the intense and deliberate deagrarianization. Socialist accumulation in former Yugoslavia brought a gap between urbanization and deagrarianization and created deeper conflicts between the village and the city. Differences created back then left the consequences that can still be felt in the rural areas. The process of transition since 2000 left even greater consequences in these areas. Serbian rural areas, as many other across Europe, are now facing the problems such as declining small-scale agriculture, abandonment of arable land, lack of investments etc. This is only a general overview of Serbian rural areas. There is a set of local characteristics unique for each rural area. In this case we are talking about different development needs, potentials and contexts within globally imposed conditions.

According to the National Program for Rural Development of the Republic of Serbia (NPRD) there is no official definition of rural areas in Serbia. ${ }^{3}$ Since the Statistical Office of the Republic of Serbia does not consider standard indicators of rurality (common in international practice) such as population density, number of inhabitants, participation of agriculture population, etc., rural areas are in most cases defined as areas that do not have a spatial plan. In the NPRD rural areas are described as territories with a high degree of differentiation in terms of: 1. natural, infrastructural and other conditions for agricultural production and for the development of other economic activities; 2. proximity to markets; 3. size and morphology of the settlements (villages). In 2009, the Republic of Serbia passed a new "Strategy for Rural Development 20092013". In this Strategy, as well as in the following documents, rural area in Serbia is defined as "an area the main physical and geographical characteristic 
of which is the primary use of land for agriculture and forestry". ${ }^{4}$ Following this definition around 70\% of territory of Republic of Serbia can be considered as a rural. ${ }^{5}$ Areas with the population density below 150 inhabitants per $\mathrm{km}^{2}$ are by the OECD (Organization for Economic Cooperation and Development) defined as rural. According to this criterion, 130 from 165 municipalities (or more precisely $85 \%$ of the territory) can be considered as rural. ${ }^{6}$

Regardless of the definition, rural areas in Serbia have the same general characteristics. These areas possess major natural resources with the rich ecosystems and biodiversity, human resources, economic activity and cultural heritage. Even though rural areas in Serbia are significantly different in social, demographic and economic characteristics, they all have similar problems regarding migration to the cities, poor diversification of economic activities, extensive agriculture as the predominant economic activity, high unemployment rate, lack of employment opportunities, poor and underdeveloped infrastructure, low GDP per capita etc. ${ }^{7}$ These parameters reveal the growth of negative trends in comparison with the urban regions, but at the same time rural areas have a better position regarding, above all, unpolluted environment. However, the present state of environment is facing potential threat that did not exist earlier: dealing with the climate change, more efficient water management, higher level of utilization of renewable energy sources, biodiversity, etc. (Serbia - Rural Development).

Rural areas are at risk, which implies that agriculture as a leading industry in these areas is also at risk. Whether we are looking at the rural areas in developed or in developing countries, the conclusions will be the same. Since they provide basic goods and services necessary for the whole population of a country, villages and rural spaces in both developed and developing countries make an equally important impact to the living conditions. ${ }^{8}$ Therefore, the problems of rural areas are becoming global. Regulating their development and treating them in theory and practice is crucial for planning sustainable future in the contemporary societies.

Despite all the negative trends, rural areas in Serbia possess significant natural resources with rich biodiversity (water resources - rivers and lakes, large areas of arable land, forest areas, etc.). Around $66 \%$ of total territory of the Republic of Serbia (excluding AP Kosovo and Metohija) is considered to be agricultural land. The National Program for Rural Development of the Republic of Serbia states that $40 \%$ of total territory is arable land, $21 \%$ is covered by perennial crops and $28 \%$ is covered by forests. ${ }^{9}$ 
Defining rural areas in Serbia and providing their overview is a complex process, since they differ in many ways. This diversity has become very important parameter of rural research. In some cases this heterogeneity is addressed as the rural mosaic, consisted of various natural and man-made structures.

Rural research in Serbia showed that one of the basic characteristics of villages and rural areas is the insufficiently developed and not well articulated network of settlements. ${ }^{10}$ Reasons for this, apart from the global ones, are:

"1. lack of the appropriate number of low order centres (most of the village population lives in the small villages distant from one another, spatially isolated, without the minimal threshold for providing of the basic technical and social infrastructural equipment); 2 . the inappropriate distribution of the services and utilities among the smaller towns in the rural region (bad connection of the towns and the rural hinterland); 3. lack of or bad spatial and functional links among the village settlements in the rural area". ${ }^{11}$

The "Serbian Village Atlas" Project should, inter alia, make the first steps towards overcoming of these problems.

\section{DEFINING SPECIFIC RURAL ZONES IN THE REPUBLIC OF SERBIA AND THE IDEA OF SERBIAN VILLAGE ATLAS}

We can define the local as pertaining to or being characterized by place or position in space. Defining the local actually means defining all of its important specificities. The local can only exist in relation to the general, common. In most of the cases local is considered as something small, relatively powerless and confined by the global. ${ }^{12}$ In this context global can be seen as a force which is transforming the local on every step of the way. On the other hand, the age of rapid globalisation brought along the growing concern for local, opening broad discussion about the autonomy of places and smaller regions. Influence of the globalisation on changes in the local character of places and regions is evident. It is even more apparent if considering peripheral, mostly rural parts of countries around the world. The prevailing concept sees globalization as a triumph of cultural and other types of homogenisation. But, its effects on rural areas are quite different. Not only that the rural areas are not homogenised during globalisation like many urban, but they differ now even more than before. People create places according to their needs. They and the "spatially-varying nature of humanly-created milieux"13 are the reasons why the places continue to differ. Place is a process that requires a cultural interpretation 
and that brings people into certain specific interconnections. ${ }^{14}$ The purpose of each cultural place is to provide a safe and continuous life of its users. Culture uses the environment and its basic functions in order to meet the physiological and spiritual needs of the people. One of the ways how this can be done is through house as a place of residence. ${ }^{15}$ Schultz believes that the creation of habitats and places to live is preceded by the identification of an individual with his environment and surroundings and understanding their meaning. By identifying with the environment, we identify with the place.

General criteria can be applied for the definition of a place and its local identity. The same criteria affect the architecture of a region. For example, climate determinism, widely accepted both in architecture and cultural geography, is based on the assumption that the primitive man built shelters that represented imperatives of climatically determined forms ${ }^{16}$ Still, climate cannot be the only determining factor. Therefore, a house is not a result of an individual factor influence, but the effect of a wide range of socio-cultural conditions. This also implies that each region has its own unique features within which the local can be recognized and defined in the context of the specific cultural place. It is then possible to define zones with the same local characteristics.

Based on these assumptions the project originally called "Rural areas in Serbia - Village Atlas" was launched in 2012. As stated earlier, the desired aim of this project is to find new ways for environmental preservation, climate change mitigation and general improvement of life quality in rural areas of Serbia. The initial idea was to create a specific database (Atlas) for future researchers in this area.

A number of recent researches have provided different typologies of rural areas in Serbia. According to the most complete one, there are four different types of the rural in Serbia: 1. highly productive agriculture and integrated economy (regions with favourable natural conditions and favourable indicators of overall economic development); 2. small urban economies with labour intensive agriculture (surroundings of urban centres with the agricultural production oriented towards intensive farming due to the market proximity); 3. natural resources oriented economies mostly mountainous (highly heterogeneous regions with economies based on exploitation of natural resources, unfavourable demographic trends and high rates of rural poverty); 4. high tourism capacities and poor agricultural structures (regions with big tourism potential and undeveloped agricultural structure). ${ }^{17}$ 
Since we initially approached this subject from the viewpoint of architecture, having in mind possibilities of climate optimization, reconstruction of rural architecture and village networking, we decided to form zones based on the same local characteristics relevant to these aspects. Thus, we added criteria such as geo-physiognomic characteristics and climate characteristics to the usual criteria of economical development, and level of urbanity/rurality often used for rural typologies. These criteria are defined as the most important and are closely related to the most important attributes of ecological villages. They are also the primary determinants for choosing the architectural and technological interventions for the possible future transformation of the existing settlements into ecological ones within the local zones.

It is important to mention that even though Serbia is relatively small, it is also a highly heterogeneous country when it comes to geography, economy, climate, cultural and historical influences etc. Geographic conditions from large plains on the north and forest regions cut by numerous rivers in the central parts to the hardly accessible mountainous regions in the south of the country, influenced the climate conditions and along with different cultural and historical influences defined economic, social and other aspects of the rural.

V. Ducić and M. Radovanović from the Geographical Institute "Jovan Cvijic" of the Serbian Academy of Science and Arts combined geo-physiognomic and climate characteristics and defined regional climate types in the Republic of Serbia. According to their research there are three basic climate types: A - continental climate, B - moderate continental climate, and C - alteredMediterranean climate; followed by a number of subtypes.

We used these findings and combined them with relevant data for economic development and the level of urbanity/rurality. For the economic development criteria, we've used five categories defined in the Serbia's Regulation on establishing a single list of regional development and local self-government: 1 . municipalities with the degree of development higher than the national average; 2. municipalities with the degree of development between $80 \%$ and $100 \%$ of the national average; 3 . municipalities with the development degree between $60 \%$ to $80 \%$ of the national average; 4 . municipalities with the level of degree lower than $60 \%$ of the national average; 5 . devastated areas (development level is below $50 \%$ of the national average).

From the Rural Development Strategy 2009-2013 we have adopted the categories for the level of urbanity/rurality criteria: 1. urban areas; 2. economically 
integrated "successful" rural areas; 3. central rural areas; 4. remote "poor" rural areas (economy oriented to natural resources); 5. remote "poor" rural areas (tourism-oriented economy).

The basic research premise was to create adequate local zones by overlapping date collected within the defined criteria. Yet, on the very beginning we have identified problems for creating accurate and precise zoning methodology that would eventually lead towards forming irrefutable local models. Problems that have occurred originate in different approaches to data collection and analysis within physical and social geography. Most of the countries administratively define data from social geography. Natural areas are complex, dynamic and changeable unlike static administrative zones. Data within social geography are mostly being provided as municipality average, bringing along a number of risks for future research and planning. Having that in mind, we decided to moderate our methodology, testing the accuracy of the date later in the research. We have defined zones as parts of municipalities within certain natural area.

By using these criteria we were able to define 22 different zones on the territory of Serbia. Some of the zones are similar by one or few criteria, but different according to other. This allows grouping of the zones depending on the type and purpose of the actions and desired development outcomes. The first part of the Serbian Village Atlas contains relevant information about the zones and can be used for providing solutions for zone development in the future.

\section{CASE STUDY: THE WEST POMORAVLJE RURAL AREA}

Here we will present the research approach and the methodology of Serbian Village Atlas project through a case study of one of the previously defined zones - the West Pomoravlje rural area.

The West Pomoravlje rural area is located in the central Serbia, south from the West Morava River and the town of Kraljevo and it includes parts of four municipalities ${ }^{18}$. In order to recognize the potential that the case study zone has for developing an eco-village network, we have analysed the zone in the context of geo-morphological, climate and economical characteristics, looking back to the social and cultural issues as well.

Even though it is geographically marked as a single zone, field visits showed high heterogeneity in every sense (Fig. 1). The West Pomoravlje zone includes the mountain ranges covered with forests and pastures, cut by the river valleys 
and basins. There are three main types of agricultural land: 1 . farming and animal husbandry in the plains (zone around West Morava river); 2. animal husbandry, fruit-growing and vineyards on the hills in the middle of the zone; 3 . animal husbandry in the mountain ranges (south parts of the zone). A large percentage of the zone is covered by forests and has a mostly preserved environment (in the highlands) (Fig. 1). There are rich water resources. The territory is cut by smaller rivers and has plenty of natural and thermal springs.

Villages are scattered around the territory - from relatively prosperous villages in the valleys to the hardly reachable, "dying" villages. The infrastructure of the plain settlements near the town is mostly developed. Those settlements have almost all necessary facilities, but the environment preservation is under question due to the fast development provoked by the proximity of the town. In other parts of the zone infrastructure is poorly developed. Some of the villages are reachable by local roads, and some only by foot.

The zone has a rich history - the first records of some villages date back to the 13 th century. In some parts traditions and customs as well as original houses are preserved, while in others gravity towards the town can be noticed.

The West Pomoravlje area has a moderate continental climate. Its specific geomorphological characteristics suggest that abrupt climate changes are usual. ${ }^{19}$ The field research confirmed this and revealed drastic climate variations: although they represent the same climate zone, towns, river valleys, hills and mountains form specific micro-climatic zones. Taking into consideration the data that have been gathered during the last decades, we were able to observe
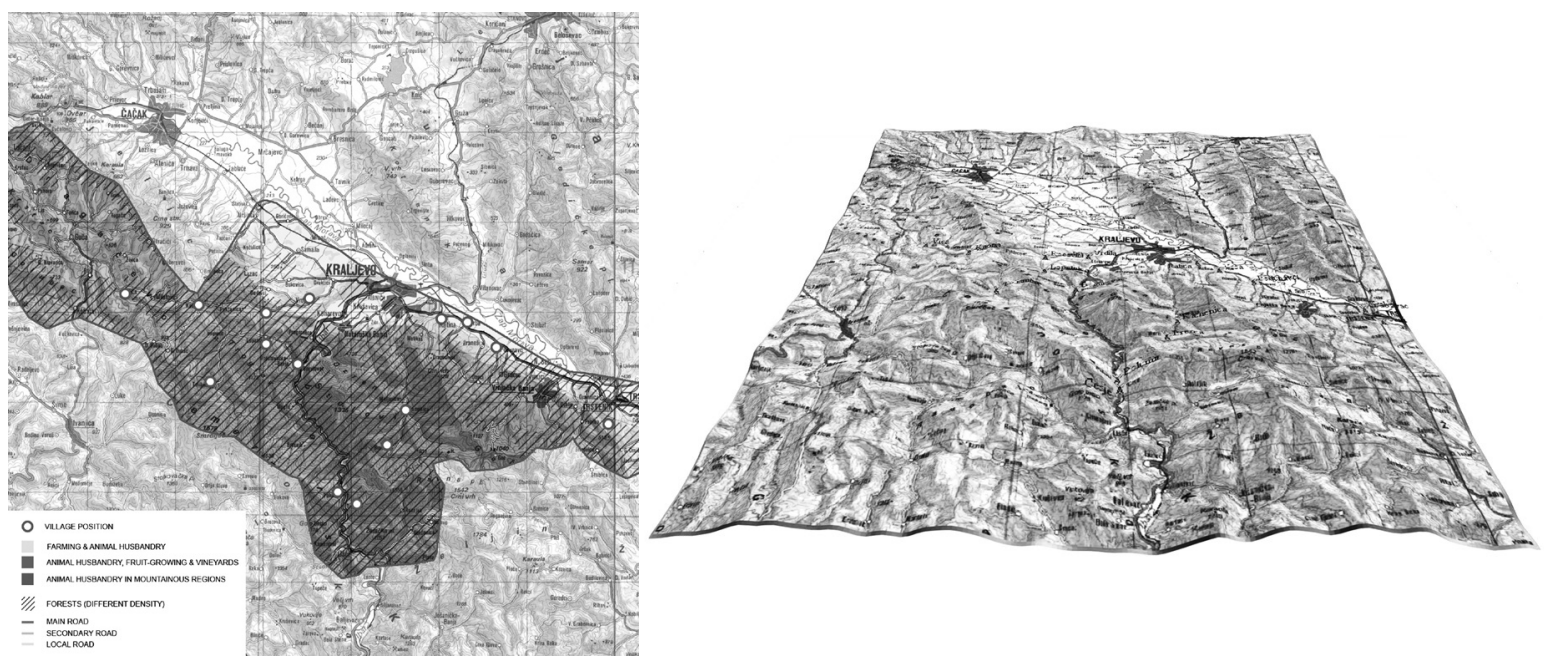

Figure 1. Map and model of the West Pomoravlje zone. 
and analyse the changes of average annual temperature and rainfall quantity for a defined territory. It is noticeable that, in the course of last six decades, there has been a slight increase in the average annual air temperature and a drastic decrease in average annual rainfall in the selected area.

Based on the data analysed in the Geographical Institute "Jovan Cvijic" of the Serbian Academy of Science and Arts in Belgrade, it was possible to analyze and observe the selected case study zone in terms of terrain exposure and slope as the geo-morphological elements relevant for the successful ecovillage networking. A number of authors point that the southern exposure with the terrain slope up to the 12 degrees represents the most favourable geomorphological characteristics from the viewpoint of ecological house design. In order to form the map of terrain exposure to the Sun and cardinal directions, eight classes were selected and presented on the map ${ }^{20}$. The map shows us that the northern exposure hardly exists at all, and that north-east, north-west and west exposures are rare. The selected location is dominated by the most favourable exposures - east, south-east, south and south-west exposure (Fig. 2). For the map of terrain slope ten categories were defined ${ }^{21}$. The map shows that the selected case study zone includes only the first seven categories and that the highest slope is 20 degrees (Fig. 3). These analyses showed that the zone has quite favourable exposures and slopes.

According to the National Strategy for Rural Development, the municipalities belonging to the regions included in this study fall under the rural region type 2, the so-called central rural area. This zone comprises the greater environment of urban centres and cities known for relatively more favourable economics in comparison to other rural parts of the country.

Population density in these municipalities ranges from 50 to 100 inhabitants per $\mathrm{km}^{2}$. The population density was defined by a satellite night shot of the zone that presents the number of lights per square kilometre. Here, we can point out that population density within the zone is relatively low. The interconnections between physiognomy (relief) and the level of density are noticeable (Fig. 4). According to the level of economic development the selected municipalities belong to the group with development level of $80 \%$ to $100 \%$ of the national average.

After analysing the zone, the research focuses on the villages. During the 19th century the villages in Serbia were developed either spontaneously or in accordance with a $\operatorname{plan}^{22}$. In remote and mountainous areas the villages 


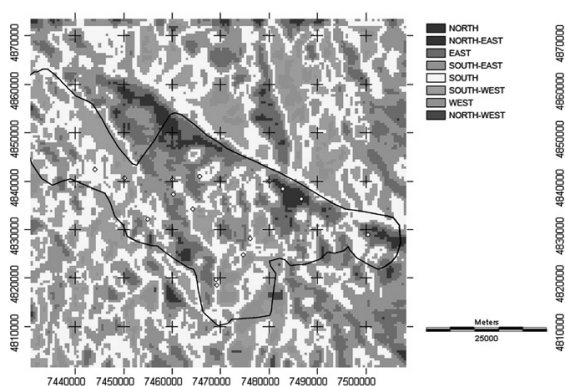

Figure 2. The map of selected zone's exposure (created by Dragoljub Strbac from the Geographical Institute SANU).

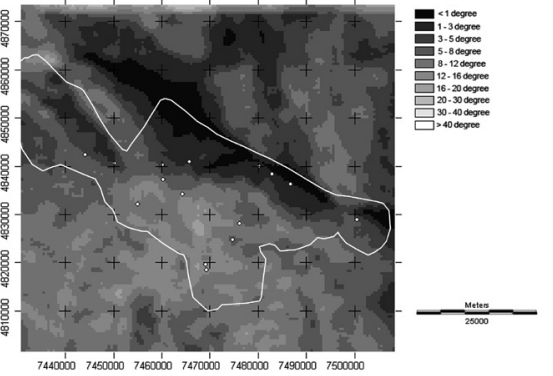

Figure 3. The map of selected zone's slope (crated by Dragoljub Strbac from the Geographical Institute SANU)

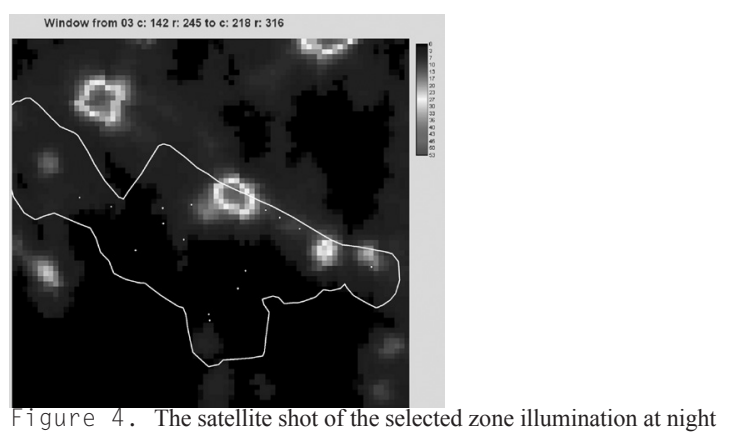

(created by Dragoljub Strbac from the Geographical Institute SANU).
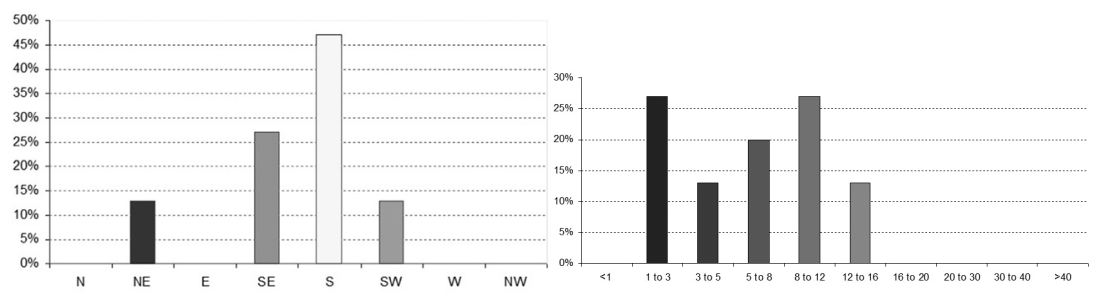

Figure 5. Doinant exposures of the villages.

Figure 6. Doinant slopes of the villages. 
evolved spontaneously. Generally speaking, most of the villages founded in the first part of the 19th century are spontaneous settlements. In accordance with morphological characteristics there are dispersed, dense and semi-dense rural settlements. Considering the size and population density rural settlements in Serbia are divided into small (up to 100 and from 100 to 500 inhabitants), medium-sized (from 500 to 1,000 and from 1,000 to 2,000 inhabitants) and large settlements (over 2,000 inhabitants). Depending on geographical position, we can recognize the villages located in the heights as well as villages in the valleys, ravines and plains. ${ }^{23}$

In order to analyse the zone more detailed a representative sample of villages should be defined. According to the Statistical Office of the Republic of Serbia, a proper representative sample contains at least quarter of all settlements from the zone (due to the high heterogeneity) and includes all specific types. Following this, we have chosen a representative sample of fifteen villages (one third of the settlements defined as villages within the zone) for further analysis. Sample villages represent the specific types in terms of genesis, morphology, size and geographical location ${ }^{24}$. In regard to the settlement genesis, selected villages were founded in a spontaneous way. As for morphological characteristics, there are three historical types of villages present in this zone, according to the relevant literature - dispersed Ibar and Stari Vlah type, semi-dense Šumadija type and dispersed-dense-Morava type. In case of a dispersed Ibar and Stari Vlah type of settlements, it is rather difficult to define a village border and housings are scattered all over the village area.

Semi-dense Šumadija type includes several more or less distant groups of households; the settlement can be defined to some extent and village location is adjusted to physiognomic-geographical characteristics.

Dispersed-dense-Morava type of settlements represents the villages where a border is easily defined. Households are located on the outskirts of streets, and public roads pass through the villages. This type of rural settlement is typical for lowland areas. Field research mostly confirmed theoretical assumptions and classified villages into these three types. It also revealed that some villages have tendency for further densification as a result of population increase due to the proximity of urban area

In the regard to the number of inhabitants, there are small, medium-sized and large villages among the selected ones. According to the comparison of census in the period from 1948 to 2012 (Republic Institute for Statistics), it is obvious 
that the large number of villages are facing the population decline. Only in the case of villages near towns the number of inhabitants has significantly increased, indicating the possible shift from rural towards suburban.

Going back to the previously discussed zone exposure and slope, the village analysis showed that the largest number of settlements have the most favourable parametres (Fig. 5 and Fig. 6).

Another important element in village assessment analysis is, by all means, rural architecture. By combining relevant literature with the field research (direct observation, surveys, individual interviews, contents analysis etc.) we were able to define five types of rural houses in the area of West Pomoravlje. Houses built in the period from 1815 to 1920 belong to the type 1 and their construction material has lower quality and durability ("bondruk" system and unbaked brick). Type 1 is the prevailing house type in the remote villages (Fig.7).

Houses that belong to the type 2 were built in the period from 1920 to 1945 . The constructive walls were made of solid materials, the floor construction was made of wood and filled with brick products (Fig. 8). Houses that belong to the type 3 were built in the period from 1945 to 1990. The constructive walls were made of solid materials, the floor construction was made of wood and filled with brick products. Houses that belong to the type 4 were built in the period from 1945 to 1990.

The constructive walls were made on the reinforced concrete foundations, the floor construction was made of reinforced concrete and other solid materials, filled with brick products (Fig.9). Houses that belong to the type 5 were built in the period from 1990 to 2010 . The constructive walls were made on the reinforced concrete foundations and the floor construction was made of reinforced concrete and other solid materials and filled with brick products. Type 5 is the prevailing house type in the villages close to the towns and main roads (Fig. 10).

All of the gathered information and the data have been classified in a form of a village passport enabling their evaluation and comparative analysis and providing suitable database for future research. 

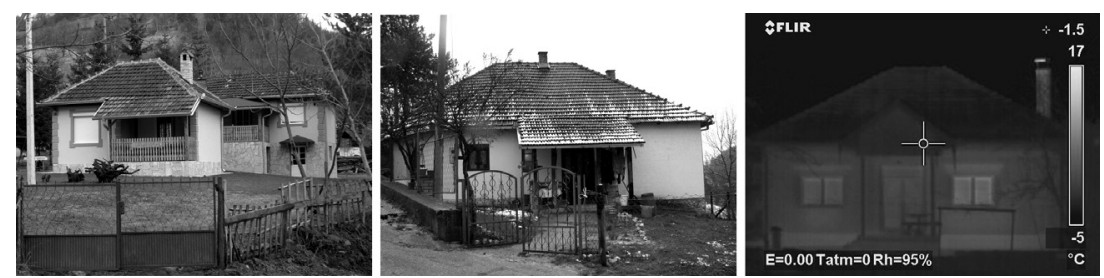

Figure 7. House type 1 and the thermo-vision photo of the construction (photo Ksenija Bunjak).
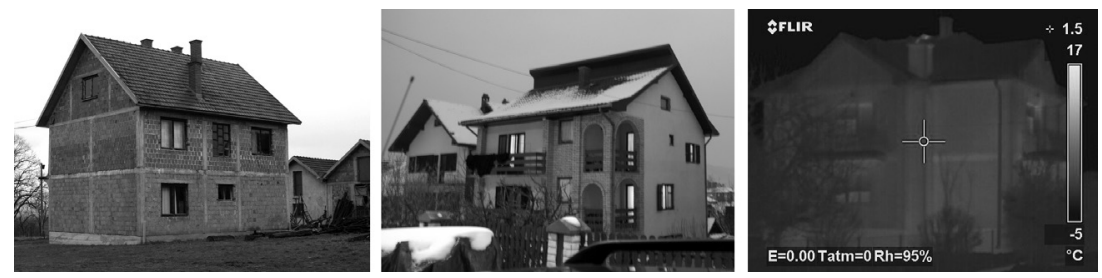

Figure 8. House type 2 and the thermo-vision photo of the construction (photo Ksenija Bunjak)
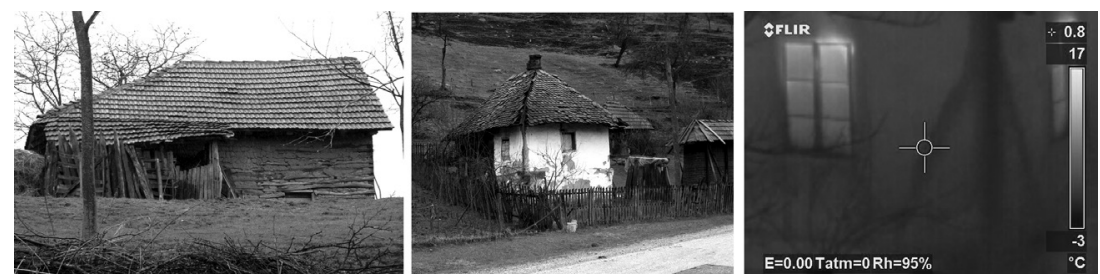

Figure 9. House types 3 and 4 and the thermo-vision photo of the construction (photo Ksenija Bunjak).
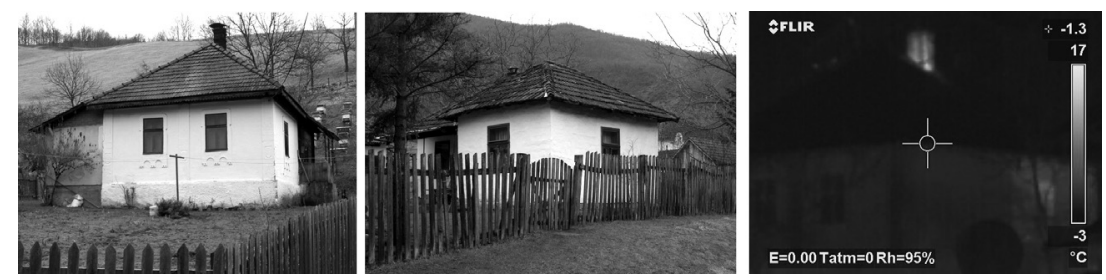

Figure 10 . House type 5 and the thermo-vision photo of the construction (photo Ksenija Bunjak). 


\section{CASE STUDY: VILLAGE OVERVIEW}

Bogutovac is a medium-sized village with the tendency of population decline. The infrastructure is relatively developed and the village connection to the main roads is good. Bogutovac is situated both on the hills and in the valley of river Lopatnica, relatively close to the gorge of the Ibar River. The village is surrounded by the mountains covered with forests, while the road along the Lopatnica River is a famous destination for cyclists and hikers. The area is rich in thermal and mineral springs and there is a famous health centre and spa nearby. The rural and spa tourism is developed up to some point. Besides tourism, animal husbandry is a main economy. Prevailing house types are 3 and 4 (Fig. 11). "We work hard during the summer to get by through winter months, when tourist interest is more focused on large ski centres" - Jovica and Darinka Filipović, ethno household "Bogut".

Brezna is a small-sized village with a strong tendency of population decline (there are no more children in the village and the school has been closed for more then two decades). The infrastructure is not developed and the village is reachable only by the local road and on foot (for more distant households). Nearest grocery and health care are kilometres away. Brezna is one of the oldest villages in the area - the first written records date back to 13th century. The village is situated on the slopes of the mountain Goč, surrounded with forests. It has a highly preserved natural environment. Animal husbandry is a main industry, but the elder residents still live on the edge of poverty. Proximity of mountain Goč as a future tourist destination creates possible development opportunities for this village. Many of old traditional houses are still being used. Prevailing house types are 1 and 2 (Fig. 12). "We don't have roads, shops, phone lines or school. Majority of residents are over 60 years old. We depend only on the surrounding nature" - Dragoslav Milašinović (81), villager.

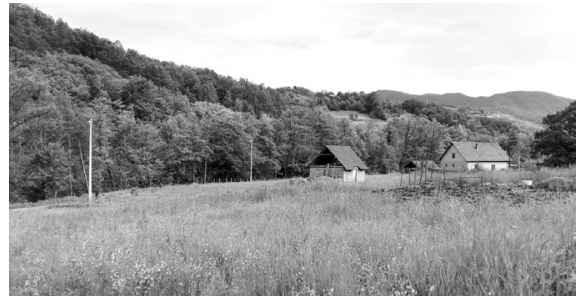

Figure 11. Village Bogutovac (photo K. Bunjak).

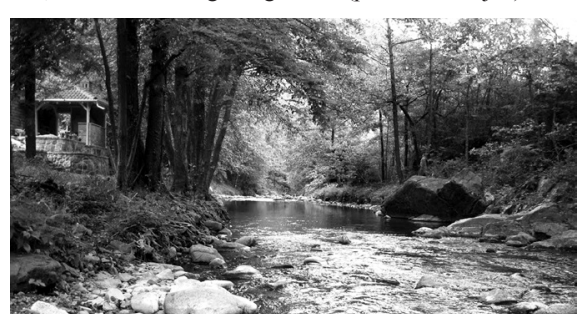

Figure 13 . Village Kamenica (from http://www. panoramio.com/photo/74897332 [15.08.2013]).

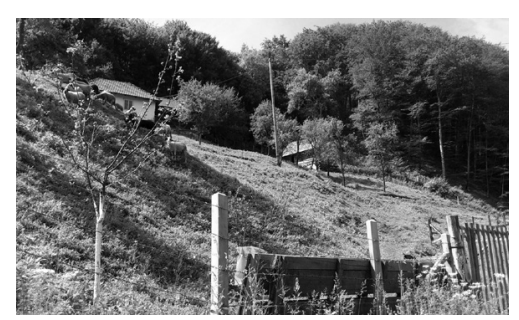

Figure 12. Village Brezna (photo K. Bunjak).

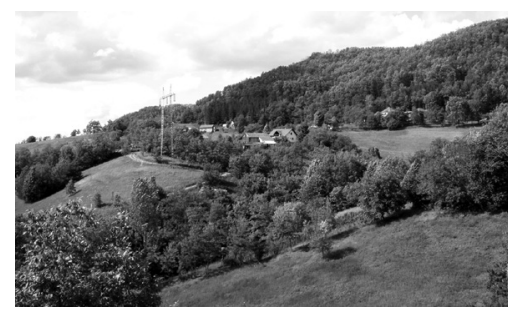

Figure 14. Village Kaona (photo K. Bunjak). 
Kamenica is a small-sized village with the tendency of population decline. Infrastructure is relatively developed and the village connection to its surroundings is good. Kamenica is situated both on the hills and in the valley of river Ribnica, on the bottom of mountain Goč. Animal husbandry, wood industry and stone quarry are the main industries. Environment is not that preserved like in other villages. Further development of tourist recreational center at mountain Goč can initiate village progress. Prevailing house types are 2 and 5 (Fig. 13).

Kaona is a small-sized village with the tendencies of population decline. Infrastructure is relatively developed and the village is well connected with its surroundings. Kaona is situated on the slopes of the mountain Jelica, half way between smaller towns Kraljevo and Guča. It is surrounded with forests and hiking tracks and has a relatively preserved environment. Animal husbandry, fruit-growing and vineyards are main agricultural activities. Kaona recently started to develop rural and hunting tourism. The village school and church have long history and they managed to preserve traditional values. The prevailing house types are 1 and 3 (Fig. 14).

Lopatnica is a small-sized village with the tendency of population decline. Infrastructure is not completely developed, so the connection with the surroundings is not quite good. Lopatnica is situated in the valley of the River Lopatnica and in the bottom of the mountain Troglav. The village is surrounded by the mountains covered with forests. The natural environment is preserved, while traditions and history are cherished. The road along the Lopatnica River is a famous destination for cyclists and hikers. There is a possibility for recreational fishing. The area is rich in thermal and mineral springs. In order to provoke further village development, residents founded ecological centre "Lopatnica". Rural tourism, education of the residents, popularisation and implementation of the ideas regarding ecological rural development are some of the centre's main actions. Besides that, animal husbandry is a core activity. The prevailing house type is 2 (Fig. 15).

Podunavci is a medium-sized village with the tendency of population rise and settlement densification due to the proximity of the town Kraljevo. The infrastructure is developed and the village is excellently connected to the surroundings. Podunavci is situated on the plain terrain in the valley of the West Morava River (the West Pomoravlje). Due to the proximity of a regional road and fast building, the environment is at risk. Farming and animal husbandry are the main agricultural industries. Many of the residents work in town, outside the agricultural sector. The prevailing house types are 4 and 5 (Fig. 16). 
Polumir and Cerje are villages with similar characteristics, not far one from another. They are small-sized villages with the tendency of population decline. The infrastructure is partially developed and the villages are well connected to the surroundings. They are situated both in the gorge of the Ibar River and on the hills around. Polumir and Cerje are close to the regional road and railway, so the environment is not quite preserved. Animal husbandry is the main agricultural branch. The once well developed tertiary sector of economy (railway, trade etc.) is declining. The prevailing house types are 3 and 4 (Fig. 17).

Ratina is a large-sized village with the tendency of population rise and settlement densification due to the proximity of the town Kraljevo. Tendencies towards transformation into the specific suburbia are evident. The infrastructure is developed and the village is excellently connected to the surroundings. Ratina is situated on the plain terrain in the valley of the West Morava River and on the right riverbank of the Ibar River. Due to the proximity of a regional road and fast building, the environment is at risk. Farming and fast-growing are the main agricultural industries, but many of the residents work in the town, outside the agricultural sector. The large percentage of the village territory is farming land. The prevailing house types are 4 and 5 (Fig. 18).

Roćevići is a small-sized village with the tendency of population decline. The infrastructure is relatively developed and the village is well connected to its surroundings. The village is situated at the hilly terrain and has quite preserved natural environment. Field crops, animal husbandry and fruit-growing are the main industries, along with the wood mills and fruit factory. The prevailing house types are 1 and 3 (Fig. 19).
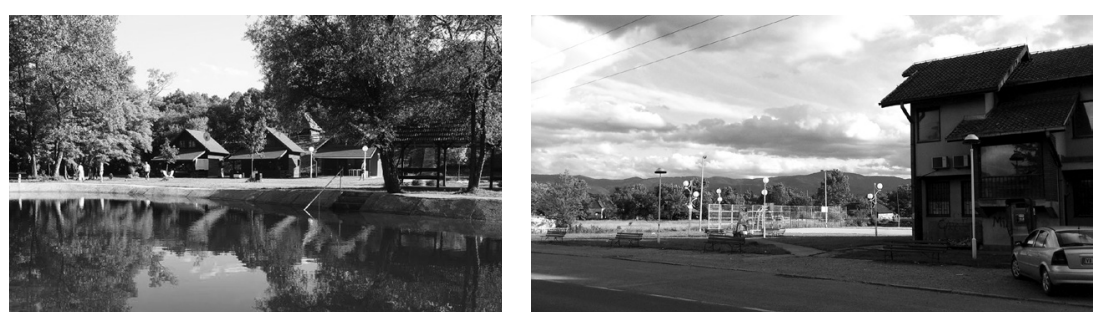

Figure 15. Village Lopatnica (photo K. Bunjak). Figure 16. Village Podunavci (photo K. Bunjak).
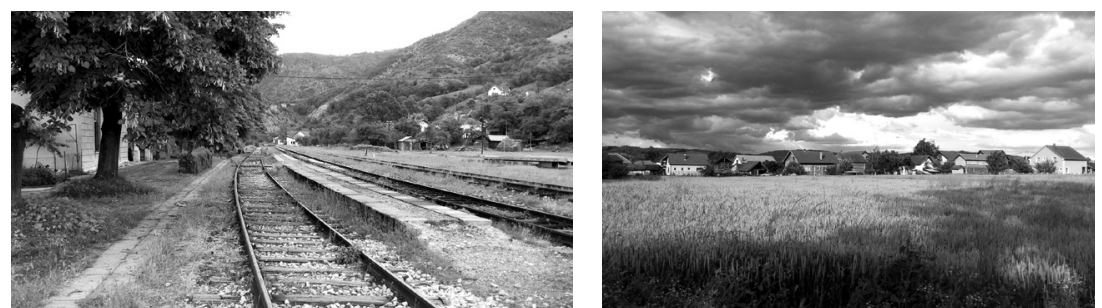

Figure 17. Villages Polumir and Cerje (photo K. Bunjak). Figure 18. Village Ratina (photo K. Bunjak). 
Tolišnica is a small sized village with the drastically population decline. Infrastructure is not developed and this remote village is reachable only by the local road or by foot (for more distant households). There are no local buses and it takes hours of walk to reach the nearest bus station or grocery shops. Tolišnica is situated in a mountainous region with sharper climate. The river Tolišnica runs through the village. Animal husbandry is the main economy, but the elder residents still live on the edge of poverty. Some households developed beekeeping as well. Tolišnica has a highly preserved natural environment - forests, mineral and thermal springs etc. The villagers tend to keep traditional values and cherish history and nature. The prevailing house types are 1 and 3 (Fig. 20). "We enjoy our nature, but it gets hard sometimes. Especially during the winter months. We need to walk to get medical help." Milatovic (73).

Viča is a medium-sized village with the tendency of population decline. Infrastructure is relatively developed and the village is well connected to its surroundings. Viča is situated on the hilly terrain covered with forests. Animal husbandry, fruit-growing and vineyards are main agricultural branches. During the season festivals the village is open for the tourists. The prevailing house types are 3 and 4 . Cultural heritage and the natural environment are quite preserved (Fig. 21).

Vrba is a medium-sized village with the tendency of population rise and settlement densification due to the proximity of the Kraljevo town. The infrastructure is developed and the village is excellently connected to the surroundings. Vrba is situated on the plain terrain in the valley of the West Morava River. Farming and animal husbandry are the main industries. Many residents work in the town, outside the agricultural sector. Among the other facilities, Vrba has an active ecological society. The prevailing house types are 4 and 5 .

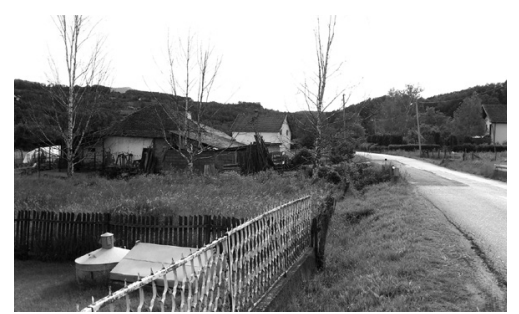

Figure 19. Village Roćevići (photo K. Bunjak).

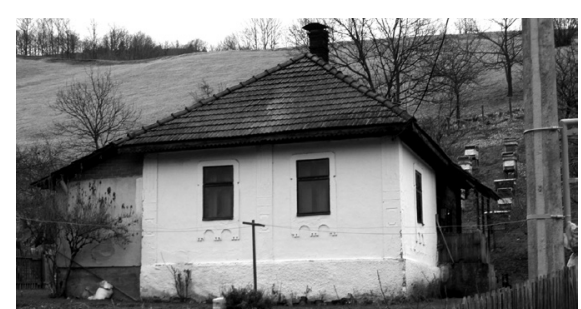

Figure 20. Village Tolišnica (photo K. Bunjak).

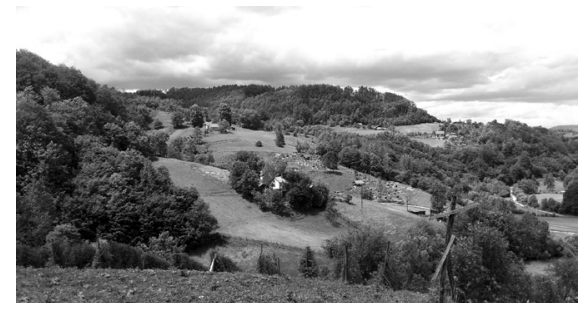

Figure 21. Village Viča (photo K. Bunjak).

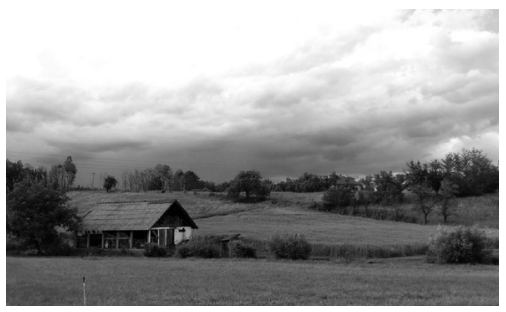

Figure 22. Village Vrdila (photo K. Bunjak). 
Vrdila is a medium-sized village with the tendency of population decline. The infrastructure is relatively developed and the village is well-connected to its surroundings. The village is situated at the hilly terrain, $10 \mathrm{~km}$ from the town of Kraljevo. Farming and animal husbandry are the main industries, along with the wood mills and fruit factory. The prevailing house type is 3 (Fig. 22).

\section{POSSIBILITIES OF CREATING ECO-VILLAGES AND ECO-VILLAGE NETWORK WITHIN THE SERBIAN VILLAGE ATLAS}

Serbia needs to invest further in improving the social and economic conditions in rural areas, and especially in the more remote rural areas that are facing depopulation, as well as in the sub-urban areas. One of the possible ways to improve the quality of life is investing in broader rural economy and improving access to basic services and infrastructure. Better environment could be established through promotion of small and medium enterprises in these areas. Although agriculture is the most important activity, non-agrarian activities should be developed as main or additional income resources for households in rural areas. One of the possible ways of doing that is through tourist sector.

Rural tourism is considered to be one of the mid-term and long-term development goals of the Republic of Serbia. ${ }^{25}$ Its territory has numerous attractive natural resources such as mountains, diverse landscapes, rivers, gorges, thermal springs and protected localities of cultural heritage. So, it is obvious that there are high potentials for the future development of the rural sector. Diverse economic gains and improvement of the sustainable development could be expected as a direct result of expansion in this sector. Rural tourism could be recognised as an important factor for orienting Serbia towards development of sustainable tourism and revival of rural areas. ${ }^{26} \mathrm{With}$ great number of unused and abandoned spaces and facilities in rural Serbia there are huge potentials for reactivation of these areas under the influence of the rural tourism.

One of the possible ways in balancing needs and potentials of the rural areas could by in developing the network of eco-villages. It would be possible to reconstruct existing villages and their built environment into sustainable communities - eco-villages.

The term eco-village came into common use in the early 1990s after Robert Gilman coined it and was frequently defined as "a human-scale settlement (usually between 50 and 500 members, though there are exceptions) that is intended to be full-featured - providing food, manufacturing, leisure, social 
opportunities, and commerce - the goal of which is the harmless integration of human activities into the environment in a way that supports healthy human development in physical, emotional, mental, and spiritual ways, and is able to continue into the indefinite future". ${ }^{27}$ However this is not the only definition of eco-village. During the years many various definitions were used by different specialists, activist and researchers. Jonathan Dawson made five principles of eco-villages. He wrote that "eco-villages are private citizens' initiatives, that they are grassroots which are not overly dependent on government, corporate or other centralized sources of water, food, shelter, power and other basic necessities". ${ }^{28}$ While writing about them, Dawson said that eco-villagers value community living and that they have strong sense of shared values, often characterised in spiritual terms. ${ }^{29}$ It is clear from these definitions that eco-villages are very often connected to the anti-globalist ideas and with new social movements that are developed as an answer to a post-industrial period. Although eco-villages have some similarities with traditional villages, it should be clear that eco-villages are a mostly post-industrial and more likely even post-agricultural phenomenon. With this specific typology of settlements we are not going backward to previous period or way of life. It is quite the opposite - we are just learning the lessons from the past while building possible sustainable strategy for the future. Having this in mind, one of the definitions for eco-villages is that they are human-scale full-featured settlements in which human activities are harmlessly integrated into the natural world in a way that is supportive of healthy human development and can be successfully continued into the indefinite future. In this research we are addressing the organizational model of eco-villages not as much as an answer to a contemporary trends and settings, but as a possible way to reconstruct existing villages in Serbia. While analysing examples from all over the world and the idea of making the network of eco-villages in Serbia we think that we should implement the existing idea that eco-villages grow out of the need and opportunities which are caused by new ecological constraints and new techniques and technologies. ${ }^{30}$

Eco-villages as a part of sustainable communities are not completely selfsufficient, and they are not meant to be like that. Eco-villages are very often suitable to be linked in social, economic and political ties in order to organise a bigger sustainable community. In this case, a more complex spatial system is created, with more or less independent parts which can function separate as well. Having this in mind, we are proposing to implement eco-villages principles in reviving Serbian villages and redeveloping rural space. Therefore, a special part of the Serbian Village Atlas project is the assessment of the villages in the context of eco-villages. Each village is subjected to SWOT analysis according 
to the four most important aspects of eco-villages: ecological, social, cultural and infrastructural. Based on this element of the Atlas, it is possible to identify villages with the biggest potential in becoming eco-villages, to map them, to compare them and to predict the most appropriate future networking between them. The Serbian Village Atlas project represents the core database for further research in this area.

After conducting the field research and necessary analysis, we noticed that there were possibilities for networking between the villages based on different aspects (ecological, social, economic factor etc.) (Fig. 25). Some of the villages showed strong tendencies towards networking, while in some cases existing networks are noticeable (especially in villages close to the town). Networking according to one aspect can provoke further connections and influence village development.

\section{CONCLUSION}

Following the statement that the local can only exist in relation to the general/ common, in our research of the local we've proposed the general methodology applicable to different types of local. The basic research involves around a specific deductive approach - using the general/common assumptions in order to form an adequate methodology for description and research of the local/ individual. Once the research is conducted and the relevant information base is prepared, the implementation of the Serbian Village Atlas should go in the other, inductive direction - from the local to the general, from local municipalities and authorities to the general ones representing the state. Introduction of the principles at the local level can influence the state level. This represents the first step towards modification of the existing national rural strategies and creation of the new ones.

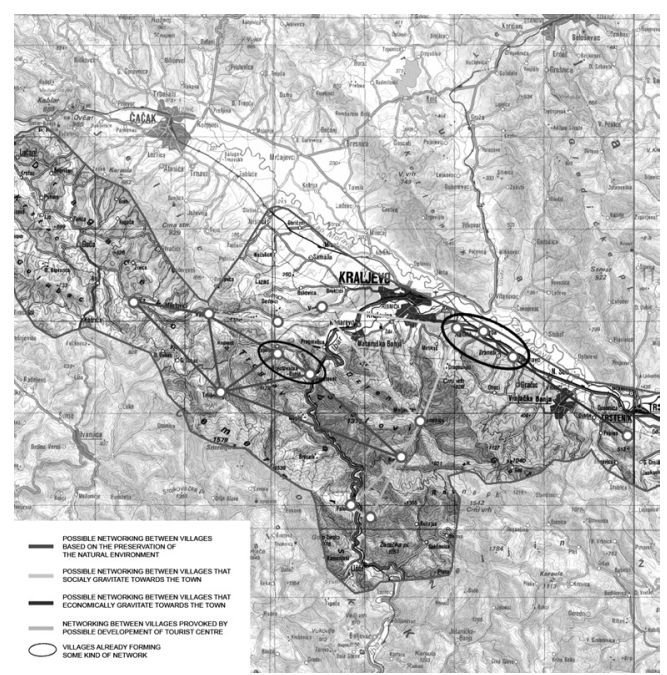

Figure 24. Possible networks between the villages. 
In our further research we plan to develop a strategy for establishing networks of different rural areas. We will try to analyse possibilities for networking villages in Serbia in present socio-political context. In order to do this we will have to point out some old ones and include the new parametres in the process of making Serbian Village Atlas such as economic status, willingness of the local communities for networking, official future plans for rural areas in Serbia, etc.

Different design guidelines for rural areas from other EU countries will be analysed. We will use existing guidelines as tools to predict changes that will occur in Serbian rural areas during the process of transition. By using these guidelines, different parameters will be selected in other to start with the organization of design guidelines for villages and rural areas in our country.

Knowing that definitions of the rural are quite different depending on cultural and economic contexts we will start establishing appropriate definitions for the rural in Serbia. We will begin with the Rural Studies and will continue with explaining the terms of the rural, regional and local especially in the discourse of architecture and sustainable development of villages. environment: impacts, adaptation and mitigation”; (43007) financed by the Ministry of Education and Science of the Republic of Serbia within the framework of integrated and interdisciplinary research for the period 2011-2014. Gore, ed. Vuksanović, D., (Univerzitet Crne Gore: Građevinski fakultet, 2005), 114. друштвеног живота села," Зборник Матице српске за друштвене науке, 101 (1996): 49-59. 
Rural Development Network of Serbia -Action Plan 2011 -2015, 2010. http://www.ruralinfoserbia. rs/dokumenta/action\%20plan\%202011\%20\%202015\%20\%20rural\%20development $\% 20$ network\%20of\%20serbia.pdf

P., Mitković, Vasilevska, 1., Bogdanović, I. S. i Dinić, M., 'Funkcionalna i veličinska tipologija seoskih naselja na teritoriji opštine Niš," Facta universitatis - series: Architecture and Civil Engineering 2, (4) (2002): 231-249.

Nacionalni program ruralnog razvoja 2011-2013. (2011), available at: http://www.ruralinfoserbia. rs/dokumenta/Nacionalni\%20program\%20ruralnog\%20razvoja.pdf

S., Đekić i Jovanović, S., 'Strategija ruralnog razvoja u svetlu priključivanja Srbije Evropskoj uniji," Facta universitatis - series: Economics and Organization 6, (2) (2009): 147-152.

P., Mitković, Vasilevska, 1., Bogdanović, I. S. i Dinić, M., 'Funkcionalna i veličinska tipologija seoskih naselja na teritoriji opštine Niš,", 232.

J. K., Gibson-Graham, ' Beyond Global vs. Local: Economic Politics Outside the Binary Frame," in Geographies of Power: Placing Scale, ed. Herod, A. \& Wright, M. W. (Oxford: Blackwell Publishers Ltd, 2008).

R., Johnston, 'A place for everything and everything in its Place," Transactions of the Institute of British Geographers, NS 16 (1991): 137.

S. E., Sutton and Susan P. K., ed. The Paradox of Urban Space. Inequality and Transformation in Marginalized Communities (New York: Palgrave Macmillan, 2011).

D. A., Mann, 'Between Traditionalism and Modernism: Approaches to a Vernacular Architecture," Journal of Architectural Education, 39 (2) (1985): 10-16.

A., Rapoport, House Form and Culture (London: Prentice-Hall International, 1969).

S., Efstratoglou, Bogdanov, N. and Meredith, D., 'Defining Rural Areas in Serbia and their Typology," in Development of Agriculture and Rural Areas in Central and Eastern Europe, ed. Tomic, D. (Novi Sad: Serbian Association of Agricultural Economists, 2007), 553-561.

Municipalities of the Republic of Serbia: Kraljevo, Lučani, Vrnjačka Banja and Trstenik.

Microclimatic characteristics are typical for the area of valleys, which is directly related to their mountainous environment. Spring is colder then autumn, and temperature oscillations are connected with elevation - temperature decrease at higher elevations. The amount of spring rainfall is reduced in comparison to autumn rainfalls from southeast to northwest areas.

Selected eight classes for the terrain exposure map (detail level 500x500 m) are north, north-east, east, south-east, south, south-west, west and north-west exposure.

Selected ten categories for the map of terrain slope (detail level 500x500 m): up to 1 degree, from 1 to 3 degrees, from 3 to 5 degrees, from 5 to 8 degrees, from 8 to 12 degrees, from 12 to 16 degrees, from 16 to 20 degrees, from 20 to 30 degrees, from 30 to 40 degrees, and over 40 degrees.

The villages "founded along the valleys of the rivers Morava, Mlava, Jasenica, Drina, Timok and Sava as well as in the surrounding valleys used to be controlled by the legislative practice; starting with the Decree on Compaction of Villages issued by Prince Miloš”. See: И., Марић, Развој народне архитектуре Централне Србије и процеси урбанизаиије (Београд: Институт за архитектуру и урбанизам Србије, 2010), 29.

Ј., Цвијић, Сабрана дела: Балканско полуострво - треће издање (Београд: САНУ и Завод за уџбенике и наставна средства, 2000).

The representative sample includes 15 villages - Tolišnica, Lopatnica, Bogutovac, Polumir, Cerje, Kaona, Viča, Roćevići, Vrdila, Brezna, Kamenica, Ratina, Vrba, Podunavci and Grabovac. Nacionalni program ruralnog razvoja 2011-2013. (2011) http://www.ruralinfoserbia.rs/dokumenta/ Nacionalni\%20program\%20ruralnog\%20razvoja.pdf

Programme of sustainable rural tourism development of the Republic of Serbia, based on the Strategy for tourism development of the Republic of Serbia and based on the National master plan for rural tourism development - document of the joint programme "Sustainable tourism in the function of rural development", implemented by five agencies of the United Nations: UNWTO, FAO, UNDP, UNEP and UNICEF, 2011.

J.M., Bang, Ecovillages: A Practical Guide to Sustainable Communities (New Society Publishers, 2005), 27. 
Bang, J.M., Ecovillages: A Practical Guide to Sustainable Communities. New Society Publishers, 2005.

Dawson, J., Ecovillages: new frontiers for sustainability. Totnes: Green Books, 2006.

Đekić S., i Jovanović, S., 'Strategija ruralnog razvoja u svetlu priključivanja Srbije Evropskoj uniji." Facta universitatis - series: Economics and Organization 6, (2) (2009): 147-152.

Efstratoglou, S., Bogdanov, N. and Meredith, D., 'Defining Rural Areas in Serbia and their Typology." In Development of Agriculture and Rural Areas in Central and Eastern Europe, edited by Tomic, D., 553-561. Novi Sad: Serbian Association of Agricultural Economists, 2007.

Gibson-Graham, J. K., 'Beyond Global vs. Local: Economic Politics Outside the Binary Frame.” In Geographies of Power: Placing Scale, edited by Herod, A. \& Wright, M. W. Oxford: Blackwell Publishers Ltd, 2008.

Mann, D. A., ' 'Between Traditionalism and Modernism: Approaches to a Vernacular Architecture." Journal of Architectural Education, 39 (2) (1985): 10-16.

Mitković P., Vasilevska, 1., Bogdanović, I. S. i Dinić, M., 'Funkcionalna i veličinska tipologija seoskih naselja na teritoriji opštine Niš." Facta universitatis - series: Architecture and Civil Engineering 2, (4) (2002): 231-249.

Nacionalni program ruralnog razvoja 2011-2013. (2011) http://www.ruralinfoserbia.rs/dokumenta/ Nacionalni\%20program\%20ruralnog\%20razvoja.pdf

Johnston, R., "A place for everything and everything in its Place." Transactions of the Institute of British Geographers, NS 16 (1991): 131-47.

Plan strategije ruralnog razvoja 2009-2013. Ministrarstvo poljoprivrede, šumarstva i vodoprivrede Republike Srbije, 2009.

Programme of sustainable rural tourism development of the Republic of Serbia, based on the Strategy for tourism development of the Republic of Serbia and based on the National master plan for rural tourism development - document of the joint programme "Sustainable tourism in the function of rural development", implemented by five agencies of the United Nations: UNWTO, FAO, UNDP, UNEP and UNICEF, 2011.

Radović, R., 'Zamagljivanje narodne graditeljske tradicije.” In Tradicionalna arhitektura Crne Gore, edited by Vuksanović, D., 111-117. Univerzitet Crne Gore: Građevinski fakultet, 2005.

Rapoport, A., House Form and Culture. London: Prentice-Hall International, 1969.

Rural Development Network of Serbia - Action Plan 2011 -2015, 2010. http://www.ruralinfoserbia. rs/dokumenta/action\%20plan\%202011\%20\%202015\%20\%20rural\%20development $\% 20$ network\%20of\%20serbia.pdf

Serbia - Rural Development, Government focal point(s): Ministry of Agriculture, Forestry and Water Management; http://www.un.org/esa/agenda21/natlinfo/countr/serbia/ruralDevelopment. pdf

Sutton, S. E., Susan P. K., ed. The Paradox of Urban Space. Inequality and Transformation in Marginalized Communities. New York: Palgrave Macmillan, 2011.

Витрувије. Десет књига о архитектури. Сарајево: Свјетлост, 1951.

Дојчиновић-Ђукић, В., “'Културна политика и сеоске институције културе као фактори друштвеног живота села.” Зборник Матице српске за друштвене науке, 101 (1996): 49-59.

Дуцић В., Радовановић М., Клима Србије. Београд: Завод за уџбенике и наставна средства, 2005.

Којић, Б., Сеоска архитектура и руризам: теорија и елементи. Београд: Грађевинска књига, 1958.

Марић, И., Развој народне архитектуре Централне Србије и процеси урбанизације. Београд: Институт за архитектуру и урбанизам Србије, 2010.

Цвијић, Ј. Сабрана дела: Балканско полуострво - треће издање. Београд: САНУ и Завод за уџбенике и наставна средства, 2000. 